\title{
Tilaa mielekkäälle työlle
}

\begin{abstract}
y
Uramuutos on ajankohtainen monen työtekijän arjessa.

Toimijuus eli kyky tehdä valintoja muutostilanteessa ei

rajoitu pelkästään työhön, vaan heijastuu myös muihin

elämänalueisiin ja identiteettiin.
\end{abstract}

TYÖELÄMÄN pelisääntöjen muutoksen myötä työn ja uran mielekkyys on alkanut huolettaa monia työntekijöitä. Mielekkyyttä nakertavat niin työsuhteiden katkonaisuus, työn jatkuva tehostaminen kuin kokemukset työn merkityksellisyyden heikentymisestä (Järvensivu 2010). Samalla subjektivoituneeseen ja yksilöllistyneeseen työhön nivoutuu myös yksilöiden minuus, mikä edellyttää itsensä toteuttamista ja kehittämistä (Julkunen 2008). Uratutkimuksessa työuria on jo pitkään luonnehdittu rajattomiksi, ja niiden on nähty tarjoavan työntekijöille aiempaa vapaammat mahdollisuudet luoda omaehtoista uraa (Arthur \& Rousseau 1996; Hall 2004; Briscoe \& Hall 2006). Uusliberalistisen politiikan myötä monessa länsimaassa työntekijöiltä myös edellytetään joustavuutta, vastuuta omasta työllistymiskyvystä sekä yrittäjämäistä otetta työntekoon (Fogde 2011; Fournier 1998; Grey 1994).
Yksilön vastuuta ja vapauksia korostava tutkimus ja politiikka ottavat kuitenkin annettuina työntekijöiden mahdollisuudet muuttaa työuraansa ja itseään. Siten ne sivuuttavat ihmisten kokemuksia ja mahdollisuuksia määrittävät, eriarvoistavat käytännöt sekä heidän subjektiviteettinsa (Arnold \& Cohen 2008; Pringle \& Mallon 2003; LaPointe 2013; Roper, Ganesh \& Inkson 2010; Sennett 1998). Tarvitsemme kipeästi monitahoisempia jäsennyksiä eri alojen työntekijöiden ja ammattilaisten mahdollisuuksista selvitä työuran monista siirtymistä, muuttaa työtä ja luoda mielekästä uraa. Tämä edellyttää toimijuuden tilan ja reunaehtojen tutkimista sekä lähestymistapoja, jotka ottavat huomioon sekä sosiokulttuurisen kontekstin että subjektiviteetin (Eteläpelto, Vähäsantanen, Hökkä \& Paloniemi 2013).

Tämän artikkelin tarkoituksena on kuvata toimijuuden mahdollisuuksia uramuutospyrkimyk- 
sissä. Uramuutokset ovat yksi, mediassakin laajalti ihannoitu keino mielekkään työn tavoitteluun ja ne tarjoavat siksi kiinnostavan kontekstin toimijuuden tarkastelulle. Teoreettinen viitekehykseni nojaa sosiokulttuurisiin, käytäntöteoreettisiin ja feministisiin lähestymistapoihin (esim. Holland, Lachicotte, Skinner \& Cain 1998; Ronkainen 1999; McNay 2000; Reckwitz 2002; Ortner 2005, Eteläpelto ym. 2013), joiden mukaan sosiaaliset, kulttuuriset ja diskursiiviset käytännöt muovaavat todellisuutta, toimintaa ja minuutta, mutta samalla niissä kuitenkin tunnistetaan minuus (subjektiviteetti ja identiteetti) toimijuuden perustana. Näiden lähestymistapojen pohjalta käsitteellistän siis toimijuuden sosiokulttuuristen käytäntöjen rajaamana sekä subjektiviteettiin pohjautuvana mahdollisuutena määritellä ja muuttaa työtään ja itseään. Uramuutospyrkimyksissä on siten olennaista kiinnittää huomiota niihin tapoihin, joilla yksilöt pyrkivät muokkaamaan työtään ja itseään sekä niitä mahdollistaviin puitteisiin.

Kirjoitus pohjautuu empiiriseen tutkimukseeni, jossa olen haastatellut uramuutosta tavoitelleita kauppatieteellisen korkeakoulutuksen saaneita eri alojen ammattilaisia kahdesti. Ensimmäisellä kerralla selvitin heidän uramuutospyrkimyksiään ja toisella kerralla, neljä vuotta myöhemmin, selvitin niiden toteutumista. Tässä artikkelissa kysyn, miten toimijuus on mahdollistunut ja miten sitä on toteutettu näissä työuran muutospyrkimyksissä. Empiirisen analyysini pohjalta kuvaan ensinnäkin sitä, miten tila toimijuudelle uramuutoksessa rakentuu vakiintuneista työkäytännöistä irtautumisen kautta ja miten toimijuutta toteutetaan pohdintavaiheessa oman tilanteen tulkinnan ja identiteettityön kautta. Toiseksi kuvaan, miten uramuutospyrkimyksissä on onnistuttu, miten eri tavoin toimijuutta on toteutettu ja mikä sitä on mahdollistanut. Lopuksi pohdin, miten toimijuuden tilaa voitaisiin laventaa ja vahvistaa siten, että huomiota kiinnitetään erityisesti subjektiviteetin ja identiteetin rooleihin käytäntöjen rajaamassa tilassa.

\section{TOIMIJUUS URAMUUTOKSESSA: KÄYTÄNNÖT, SUBJEKTIVITEETTI JA IDENTITEETTITYÖ}

Toimijuudessa on kysymys yksilöiden mahdollisuudesta tehdä valintoja ja muuttaa elämäänsä ja työtään. Sitä on teoretisoitu monin eri tavoin useilla tieteenaloilla ja täysin erilaisiin filosofisiin perusoletuksiinkin nojautuen (Emirbayer \& Mische 1998; Hitlin \& Elder 2007; Eteläpelto ym. 2013). Toimijuutta on tarkasteltu sekä rakenteiden ja niitä ylläpitävien käytäntöjen että yksilön näkökulmasta tai nämä yhdistäen (Ojala 2010). Rakenteita korostavissa näkökulmissa yksilöiden toimijuuden ja refleksiivisyyden tila on usein vähäinen. Esimerkiksi poststukturalististen näkemysten mukaan subjektiviteetti ja toimijuus muotoutuvat vakiintuneissa ajattelu- ja puhetavoissa eli kielessä, diskursseissa ja kertomuksissa. Tällöin toimijuuden tilaksi jää näiden diskurssien vastustaminen ja toisin toistaminen (esim. Judith Butler, kts. McNay 2000; Fenwick 2006). Kuten McNay (2004) esittää, nämä näkökulmat määrittelevät toimijuuden negaation kautta, eli voimme toimia toisin, koska diskurssit eivät ulotu koskaan sääntelemään kaikkea toimintaa. Ne eivät siis määrittele tarkemmin, mistä toisin toimiminen saa resurssinsa ja sisältönsä. Yksilönäkökulmaa korostavat lähestymistavat puolestaan irrottavat ihmisen eriarvoistavista käytännöistä ja tekevät hänestä lähes kaikkivoipaisen (Ojala 2010).

Yhdistän tutkimuksessani rakenteet ja yksilön tarkastelemalla ammattilaisten kokemuksia ja toimijuutta sosiokulttuuristen käytäntöjen rajaamana ja subjektiviteettiin pohjautuvana mahdollisuutena määritellä ja muuttaa työtään ja itseään. Käytäntöteoreettisten lähestymistapojen mukaan sekä rakenteet että yksilöt muodostuvat sosiaalisissa, kulttuurisissa ja diskursiivisissa käytännöissä. Nämä käytännöt määrittävät ja ohjaavat todellisuuttamme ja toimintaamme ja muokkaavat myös minuuttamme - subjektiviteettia ja identiteettiä (Lave \&Wenger 1991; Holland ym. 1998). Käytännöt ja niihin sisältyvät vakiintuneet toiminta- ja ajattelutavat (diskurssit ja kertomukset) opitaan osallistumalla erilaisten yhteisöjen toimintaan, kuten tiettyyn työhön tai ammattiin (Lave \& Wenger 1991). Aikaa myöten ne kehollistuvat automaattisiksi ja itsestäänselviksi osaamisiksi, arvostuksiksi, rutiineiksi ja tiedoksi (Sandberg \& Tsoukas 2011). Siten emme välttämättä aina tiedosta, miksi teemme työtämme, mitä siinä tavoittelemme ja miten sitä teemme (Räsänen \& Trux 2012). 
Käytännöt eivät kuitenkaan deterministisesti määritä toimintaamme, vaan toimijuus on mahdollista niiden toistamisessa improvisoiden tai tietoisemman vaihtoehtoisten toimintatapojen luomisen kautta (Certeau 1984; Emirbayer \& Mische 1998).

Uramuutoksessa ei ole kysymys vain arkisesta toisin tekemisestä, vaan siinä tarvitaan vahvempaa ja luovempaa toimijuutta - kokonaan uusien käytäntöjen ja identiteettien omaksumista. Jotta tämä olisi mahdollista, se edellyttää tietoiseksi tulemista omaa toimintaa ohjaavista käytännöistä. Pragmatistit puhuvat muutosyllykkeistä, jotka häiritsevät totunnaista vuorovaikutusta ja siten yksilön ja käytäntöjen suhdetta (Alhanen 2013). Holland ym. (1998) kuvaavat tätä tilannetta hermeneuttiseksi hetkeksi, jolloin automaattinen toiminta katkeaa ja alamme tarkastella tietoisemmin omaa toimintaamme. Tulkintaa uramuutostilanteesta ohjaavat erilaiset työelämää kehystävät diskurssit ja kertomukset eli vakiintuneet puhe- ja ajattelutavat, joihin sisältyy erilaisia perusoletuksia ja arvoja työstä. Miten siis kykenemme itsenäiseen ajatteluun, luovaan toimintaan ja muutokseen sosiaalisten ja diskursiivisten käytäntöjen puitteissa? Nojaudun seuraavassa sosiokulttuuriseen ja feministiseen ajatteluun, jossa minuus eli subjektiviteetti ja identiteetti nähdään oppimisen ja toimijuuden perustana (McNay 2000, 2004; Ortner 2005; Eteläpelto ym. 2013; Billett 2006; Blackman, Cromby, Hook, Papadopoulos \& Walkerdine 2008).

Ymmärrän subjektiviteetin ihmisen tietynlaisuudeksi - tavoiksi toimia, ajatella ja tuntea (Ortner 2005; Ronkainen 1999; Blackman, Cromby, Hook, Papadopoulos \& Walkerdine 2008). Se on maailmassa olemisen tapa, joka on sosiaalisesti ja kulttuurisesti muotoutunut eletyn kokemushistorian ja käytäntöjen kautta (Ronkainen 1999; McNay 2004). Toisin kuin arjen ja psykologian käsitys yksilöistä ja minuudesta muusta ympäristöstä erillisenä persoonallisuuden piirteiden kimppuna subjektiviteetti on siis sosiokulttuuristen käytäntöjen ja diskurssien muovaamaa. Ajan kuluessa subjektiviteetti kehollistuu ja rutinoituu ja on siten usein tiedostamatonta minuuttamme. Tämä kokemusten kautta muodostunut subjektiviteetti on perusta toimijuudelle, mutta se tulee merkitykselliseksi ja tietoisen työskentelyn piiriin identiteettiemme kautta. Identiteettimme kuvaavat käsitystä itsestämme ja ovat minuutemme artikuloidumpi puoli, jota kykenemme kielen, diskurssien ja kertomusten avulla sanoittamaan ja tekemään ymmärrettäväksi (Ronkainen 1999). Identiteettimme rakentuvat meille tarjoutuviin mahdollisiin identiteettipositioihin niissä käytännöissä ja maailmoissa, joihin osallistumme (Davies \& Harré 1990; Holland ym., 1998). Identiteettien kautta kiinnitymme erilaisiin olemisen ja tekemisen tapoihin suhteessa esimerkiksi ammattiin, sukupuoleen, ikään ja kansallisuuteen. Siten esimerkiksi ammatillinen identiteettimme tarkoittaa niitä identiteettipositioita, joihin itsemme kulloinkin voimme asemoida ammattikäytäntömme diskursseissa ja kertomuksissa.

Identiteettimme eivät kuitenkaan ole selvärajaisia tai pysyviä, vaan ajan, paikan ja kulttuurin myötä muuttuvia (Kondo 1990). Siksi joudumme tekemään identiteettityötä, jonka kautta luomme, muokkaamme ja vahvistamme identiteettejämme kulttuuristen diskurssien ja erityisesti kertomusten puitteissa (Sveningsson \& Alvesson 2003). Kertomalla jäsennämme elämäämme ja työtämme ja samalla asemoimme itseämme (Davies \& Harré 1990; DeFina, Schiffrin \& Bamberg 2006). Identiteettityö on myös ammatillisen toimijuuden muoto (Eteläpelto ym. 2013), jonka kautta voimme pyrkiä määrittelemään, keitä olemme ja kuinka toimimme työelämässä. Se on olennainen osa oppimista ja kehittymistä työssä sekä sopeutumista työelämän muutoksiin (Billett 2006). Työuran siirtymävaiheissa identiteettityö on erityisen tärkeää, sillä muutoksen toteutuminen edellyttä identiteetin muutosta (Ibarra 1999; Pratt, Kaufman \& Rockmann 2006; Ibarra \& Barbulescu 2010).

Tässä tutkimuksessa lähestyn siis toimijuutta sosiokulttuuristen käytäntöjen ja subjektiviteetin tehtyinä valintoina, tekoina ja identiteettityönä. Esittelen seuraavaksi empiiristä tutkimustani ja sitä, miten olen analysoinut toimijuutta, sen mahdollistumista ja toteuttamista uramuutosta tavoittelevien ammattilaisten haastatteluiden perusteella.

\section{TUTKIMUKSEN TOTEUTUS}

Artikkeli perustuu väitöskirjatutkimukseeni (LaPointe 2011). Haastattelin tutkimustani varten 
12 Suomen ekonomiliiton eli SEFEn urapalvelun asiakasta, jotka suunnittelivat uramuutoksen tekemistä. Ensimmäiset haastattelut tein vuonna 2005 ja seurantahaastattelut vuonna 2009. Tämä artikkeli pohjautuu niiden kahdeksan ihmisen haastatteluihin, jotka tavoitin molemmilla haastattelukerroilla. Kaikilla oli kauppatieteellinen korkeakoulututkinto ja he olivat hakeutuneet SEFEn uraneuvojan luokse hakemaan apua uramuutospyrkimyksissään. He ovat kaikki naisia, iältään ensimmäisellä haastattelukerralla 33-52 vuotta. Miehiä ei SEFEn kautta onnistuttu pitkittäistutkimukseen tavoittamaan. Vaikka identiteettityö onkin sukupuolittunutta (kts. LaPointe 2013), en tässä artikkelissa paneudu siihen.

Toteutin haastattelut kertomuksellisina haastatteluina (Mishler 1986; Hyvärinen \& Löyttyniemi 2005). Kertomukselliset haastattelut ovat strukturoimattomia keskusteluja, joissa kutsutaan haastateltavat tuottamaan kertomuksia kokemuksistaan muutaman laajan kysymyksen avulla (Riessman 2008). Oma pääkysymykseni ensimmäisissä haastatteluissa kutsui ammattilaisia kertomaan aiemmasta urastaan ja silloisesta uramuutosvaiheesta. Seurantahaastatteluissa pyysin heitä kertomaan, mitä heille oli neljän vuoden aikana tapahtunut. Nämä alustavat kysymykset tuottivat usein pitkiä selontekoja, joiden pohjalta esitin tarkentavia lisäkysymyksiä eri vaiheista. Haastattelut olen nauhoittanut ja litteroinut sanatarkasti. Lisäksi olen litteroinut valikoituja kohtia aineistosta tarkemmin kiinnittäen huomiota taukoihin, äänensävyihin ja muihin ilmaisuihin.

Aineistoa olen analysoinut hyödyntämällä useampia kertomuksellisen analyysin menetelmiä (Frost 2009). Identiteettityön osalta olen tarkastellut yksityiskohtaisesti, kuinka identiteettejä kielellisesti ja kertomuksellisesti rakennetaan ja otetaan käyttöön. Tässä olen hyödyntänyt dialogista narratiivista analyysiä, jonka mukaisesti analysoin haastateltavien kerrontaa temaattisesti, rakenteellisesti ja vuorovaikutuksen näkökulmasta (Riessman 2008). Toisin sanoen kiinnitin huomiota siihen, mistä haastateltavat puhuivat (teemat), miten he puhuivat (rakenne) sekä miten kerrontatilanne (haastattelu, vuorovaikutus, laajempi kulttuurinen konteksti) vaikuttavat kerrontaan. Lisäksi analysoin tarkemmin kunkin haastateltavan kertomukseen sisältyviä käännekohtia ja ydinepisodeja, joissa käytetään paljon evaluoivaa kieltä ja identiteettityö on usein aktiivista (Hyvärinen 2010). Tämän analyysin kautta rakensin ensimmäisten haastattelujen pohjalta mallitarinat, joilla tarkoitetaan kulttuurisia tapoja luoda järjestystä kokemuksiin, arvioida niitä ja samalla rakentaa kertojan identiteettiä (Linde 1993). Tunnistamani kolme mallitarinaa antavat muutosvaiheelle juonen ja selityksen sekä rakentavat ammattilaisten identiteettiä.

Identiteettityön lisäksi olen tarkastellut toimijuuden mahdollistumista ja toteutusta haastattelukerronnan temaattisen analyysin pohjalta. Sen avulla olen tunnistanut uramuutosprosessin vaiheita ja haastateltavien omia valintoja ja tekoja muutoksen toteuttamiseksi. Lisäksi olen tarkastellut toimijuuden resursseja eli subjektiviteettiin, kokemushistoriaan ja identiteettiin liittyviä erityispiirteitä, jotka ovat mahdollistaneet muutoksia uran tai identiteetin muutoksessa.

Esitän seuraavaksi analyysini tulokset kolmessa osassa: ensin kuvaan toimijuuden tilan ja uramuutospyrkimysten syntymistä, toiseksi identiteettityötä yhtenä toimijuuden muotona uramuutoksen pohdinnassa ja lopuksi toimijuuden muotoja ja mahdollistumista uramuutoksen toteutuksessa. Alla oleva taulukko esittää taustatiedot haastateltavista (nimet ovat pseudonyymejä), kunkin mallitarinan sekä työtilanteen ensimmäisellä ja toisella haastattelukerralla. Joitakin yksityiskohtia on muutettu anonymiteetin suojelemiseksi.

\section{TILAA URAMUUTOKSELLE}

Puhuessaan kokemuksistaan haastateltavat selittivät uramuutospyrkimyksiään erilaisten kertomusten avulla. Analyysin pohjalta loin kolme uramuutostarvetta jäsentävää mallitarinaa: murtumis-, yhteensopimattomuus- ja uudistumiskertomuksen. Murtumiskertomuksissa keskeisenä juonena oli aiemman uran kyseenalaistuminen työssä sattuneiden vastoinkäymisten johdosta. Esimerkiksi rahoitusalalla toimiva Eila oli julkisella sektorilla tehdyn pitkän uran jälkeen siirtynyt pörssiyrityksen leipiin, tullut pian sen jälkeen irtisanotuksi ja koki sitten, ettei halunnut enää toimia koko alalla. Hotellialaa kutsumuksenaan pitänyt myyntipäälikkö Kati oli kokenut tulleensa 


\begin{tabular}{|c|c|c|c|c|c|}
\hline $\begin{array}{l}\text { Haasta- } \\
\text { teltava }\end{array}$ & $\begin{array}{l}\text { lkä } \\
\text { (2005) }\end{array}$ & Perhe & Mallitarina & $\begin{array}{l}\text { Ammatti/työ } \\
\text { (2005) }\end{array}$ & $\begin{array}{l}\text { Uusi koulutus/ } \\
\text { ammatti/työ (2009) }\end{array}$ \\
\hline Eila & 52 & $\begin{array}{l}\text { Naimisissa, } \\
\text { kaksi lasta }\end{array}$ & Murtumiskertomus & $\begin{array}{l}\text { Rahoitusalan asiantuntija, } \\
\text { työtön }\end{array}$ & $\begin{array}{l}\text { Useita ma. työsuhteita } \\
\text { laskentatoimen tehtävissä }\end{array}$ \\
\hline Kati & 35 & Naimaton & Murtumiskertomus & Myyntipäällikkö, hotelliala & \\
\hline Eeva & 51 & Naimaton & Murtumiskertomus & $\begin{array}{l}\text { Liiketoiminnan kehityksen } \\
\text { asiantuntija, IT-ala }\end{array}$ & Tohtoriopiskelija \\
\hline Maria & 33 & Kihloissa & $\begin{array}{l}\text { Yhteensopimat- } \\
\text { tomuuskertomus }\end{array}$ & $\begin{array}{l}\text { Liiketoiminnan } \\
\text { kehityspäällikkö, IT-ala, } \\
\text { työtön }\end{array}$ & $\begin{array}{l}\text { Täydennyskoulutus-ohjelma, } \\
\text { HR-päällikkö IT-ala }\end{array}$ \\
\hline Riitta & 51 & $\begin{array}{l}\text { Naimisissa, } \\
\text { neljä lasta }\end{array}$ & $\begin{array}{l}\text { Yhteensopimat- } \\
\text { tomuuskertomus }\end{array}$ & Viestintäalan ma. tehtävissä & $\begin{array}{l}\text { Teologian maisterin tutkinto, } \\
\text { seurakuntapappi }\end{array}$ \\
\hline Sari & 38 & $\begin{array}{l}\text { Naimisissa, } \\
\text { kolme lasta }\end{array}$ & $\begin{array}{l}\text { Yhteensopimat- } \\
\text { tomuuskertomus }\end{array}$ & Tutkija & Myyntipäällikkö, viiniala \\
\hline Johanna & 45 & Naimaton & Uudistumiskertomus & Controller, tutkimuslaitos & Toimistopäällikkö tilitoimistossa \\
\hline Taina & 39 & $\begin{array}{l}\text { Eronnut, } \\
\text { kaksi lasta }\end{array}$ & Uudistumiskertomus & $\begin{array}{l}\text { IT controller, } \\
\text { lääketeollisuus }\end{array}$ & $\begin{array}{l}\text { Erilaisia opintoja, määräaikai- } \\
\text { sissa laskentatoimen tehtävissä }\end{array}$ \\
\hline
\end{tabular}

Taulukko. Haastateltavat, mallitarinat ja uramuutokset.

syrjityksi ylennysprosesseissa ja oli lopulta kovatahtisen työn ja siitä seuranneen työuupumuksen takia joutunut sairauslomalle. Nämä vaiheet saivat hänet miettimään alan vaihdosta:

"Mut niinkun se että mun tehtävä on tuottaa rahaa firmalle, niin se ei nyt jotenkin, se on ruvennut tuntuu et mitä merkitystä sillä on. Koska kaikessa on, tavallaan se työn merkitys on muuttunut tai se mitä mä ajattelen siitä on myös muuttunut. Et mul on tullut semmonen ajatus siitä et mä haluisin tehdä jotain, millä ois jotain merkitystä. Et sit mä oon ruvennu sitä miettimään että mitä se nyt vois olla."

51-vuotias Eeva taas toimi liiketoiminnan kehittämisen parissa it-alalla ja koki, ettei hänen monipuolista, pitkälti ulkomailla hankittua osaamista ja yrittäjyyskokemusta otettu hänen työpaikassaan vakavasti.

Yhteensopimattomuuskertomuksissa työ ei ollut pitkään aikaan tuntunut omalta. Ammattilaiset kertoivat monista hetkistä, jolloin käsitys itsestä tuntui olevan ristiriidassa tehdyn työn kanssa. Esimerkiksi liiketoiminnan kehitystehtävissä tai kehityksen johtotehtävissä toiminut Maria kertoi erään koulutuksen yhteydessä tehdystä persoonallisuusanalyysistä, joka puki sanoiksi hänen epäilynsä soveltuvuudestaan liiketoimintaan:

"Hän (psykologi) totes et ei oo ihan tyypillinen, et aika harva johtaja on tällanen. Ei niinkun yllätä ollenkaan, et tosiaan siinä mielessä oli itse luopunut et businessmaailma ei sinänsä oo ihan mua varten jotenkin tai mä en oo siellä ihan kotonani sit kuitenkaan."

Menetettyään silloisen työnsä mittavan irtisanomisaallon seurauksena Maria ryhtyi aktiivisemmin hakeutumaan uudelle alalle. PR-tehtävissä ja kotiäitinä työskennellyt Riitta puolestaan ajoitti ensimmäiset epäilyksensä jo oman valmistumisensa jälkeiseen aikaan, jolloin hänestä oli tuntunut, ettei tehnyt omannäköistä työtään. Vasta lasten kasvettua, pätkätöissä työskennellessään, hänellä oli aikaa tutkailla uusia mahdollisuuksia: hän alkoi lukea teologista kirjallisuutta ja jossain vaiheessa "huvikseen" teologisen pääsykoekirjoja.

Tutkijana jo pitkään toiminut Sari taas oli pysynyt työssään, koska se oli arvostettua, hyväpalkkaista, haastavaa ja tarjosi perhe-elämän vaatiman joustavuuden. Hän ei kuitenkaan kokenut olevansa omalla alallaan ja pohti muutosta pitkään:

"Se alko vahvistumaan mulla se ajatus kyllä, et mitäköhän mä rupeen sit oikeesti tekemään. Et mä en identifioinu itseäni koskaan tutkijaksi. Mä en koskaan tuntenut olevani taloustutkija ja jotenkin sitä kautta niin mä en aivan täysin kokenut sitä työyhteisöä niinkun aivan täysin mun. Mul oli vähän semmonen vieras olo." 
Lievän uupumuksen jälkeen hän vihdoin päätti ryhtyä toimeen, otti sapattivapaata ja alkoi aktiivisesti pohtia uusia uravaihtoehtoja.

Uudistumiskertomuksissa puolestaan haetaan uutta innostusta ja suuntaa omaan työhön osana laajempaa elämänmuutosta. "Työ on työtä", oli laskennan parissa koko uransa työskennellyt Taina aina ajatellut mutta avioeron jälkeen hän ryhtyi miettimään, voisiko tehdä jotain mielekkäämpää. Johanna, joka myös toimi laskenta-ammattilaisena, tunsi itsensä kiireiseksi ja koki kehittymisensä pysähtyneen. Työnsä vastapainoksi Johanna aloitti melontaharrastuksen, joka sai hänet huomaamaan, mitä silloisesta työstä puuttuu:

"Et tarttis saada vähän ilmaa. Et tulis ees jotenkin vähän lyhyemmät työpäivät eikä olis niin kiire. Et semmosta ehkä niinku hakee. Ja tekis semmosta että, et mihin vois innostua, mikä veis mukanaan."

Uramuutospyrkimyksiä jäsentävät kertomukset kuvaavat, kuinka jokin muutos joko työssä tai yksityiselämässä on tuonut etäisyyttä silloiseen työhön ja siten luonut tilaa toimijuudelle ja uramuutoksen pohdinnalle. Joillekin muutosyllykkeenä on ollut kriisi, esimerkiksi työsuhteen päättyminen, sairausloma tai avioero. Ne ovat luoneet tilaa muutokselle, kun mieli ja keho ovat hetkellisesti irrottautuneet arkisesta työstä ja sen käytänteistä. Uusi tila voi aueta myös kevyemmin harrastuksista, jotka antavat näkökulmia oman uran ja identiteetin pohtimiseen. Myös uraohjaus on tarjonnut kaikille tutkimuksen ammattilaisille uuden työn ja identiteetin kokeiluareenan. Käytäntöteoreettisesti tulkittuna näissä tilanteissa ja uusissa toimintatiloissa keho on jo uusilla urilla, vaikkei tilanteesta varsinaista uramuutosta seuraisikaan. Muutostilanteissa kuitenkin toimitaan toisin, ollaan toisenlaisia ja saadaan toisenlaisia ajatuksia. Siten niissä mahdollistuvat uudet elämän ja työn käytännöt sekä identiteetit.

Uramuutostarpeen jäsentämistyössä avautuu tilaa toimijuudelle ja sitä myös toteutetaan. Omaa tilannetta tulkittuaan haastateltavat ovat päättäneet tavoitella nimenomaan uramuutosta sen sijaan, että olisivat tyytyneet nykyiseen työhönsä tai alaansa. Ulkoisesti samanlaisissa tilanteissa kaikki eivät kuitenkaan päädy tällaiseen johtopäätökseen. Ehkä koulutuksen- sa ja keskiluokkaisen taustansa vuoksi uramuuttajan asema näyttäytyy näille ammattilaisille mahdollisena ja luonnollisenakin vaihtoehtona. He ovat myös osallistuneet uraohjaukseen, joka on selkeä teko, siirtymä sisäisestä pohdiskelusta aktiivisempaan toimintaan. Lisäksi ammattilaiset tekevät valintoja sen suhteen, miten he selittävät omaa muutostarvettaan eli millaisen kertomuksen puitteissa he sitä sanoittavat ja perustelevat. Näitä valintoja toteutetaan kuitenkin kulttuuristen käytäntöjen ja niihin pohjautuvien mallitarinoiden sekä oman kokemushistorian ja subjektiviteetin puitteissa.

\section{IDENTITEETTITYÖ URAMUUTOKSEN POHDINNASSA}

Selittäessään ja sanoittaessaan uramuutostarvettaan ammattilaiset tekevät samalla myös identiteettityötä. He pohtivat itseään suhteessa työhönsä, ammattiinsa ja uraansa, kuten yllä olevat lainauksetkin osoittavat. Samoin kuin muutakin tulkintaa, identiteettityötä tehdään mallitarinoiden puitteissa. Ammattilaiset asemoituvat niiden tarjoamiin identiteettipositioihin ja rakentavat samalla käsitystä itsestään tietynlaisina ammattilaisina. Murtumiskertomuksissa aiemmin hyvältä tuntunut ammatillinen identiteetti on hukassa ja alan vaihto näyttäytyy ainoana vaihtoehtona. Uramuuttajaksi asemoituminen vahvistaa kuitenkin identiteettiä pätevänä ja omatoimisena ammattilaisena, sillä se korostaa sitkeyttä ja joustavuutta vaikeuksista huolimatta. Tätä kuvaa Katin kuvaus sairauslomalle jäämisestä uupumuksen vuoksi:

"Että siinä määrin että mä olin viime syksynä uupumisen takia pois töistä, kylläkin vaan viikon, mutta kuitenkin sanotaan että sekin että mä menen ja totean kollegoille että nyt tippu kynä käytännössä katsoen että mä en jaksa yhtään mitään. Niin se on vaan et mähän oon hirveen pitkäjännitteinen ihminen ja oppinut kestämään melkein mitä vaan ja tullut toimeen aina tavallaan omillani. Tietty tämmönen sitkeys ja pinnan venyttäminen on mulle ihan ominaista. Mutta tota, et sen takia siinä meni niin kauan kun mä totesin et nyt ei niinku, nyt ei enää jaksa. Et mä oon todennut sen että en mä tossa duunissa, se vie niin multa mehut." 
Yhteensopimattomuuskertomuksissa keskeistä on aidon ammatillisen identiteetin tavoittelu, mikä rakentaa ammattilaisille identiteettiä rohkeina itsensä toteuttajina. Uudistumiskertomuksissa päällimmäisenä ei ole alan vaihto vaan uudistuminen ja sitä kautta ammatillisen identiteetin vahvistaminen esimerkiksi urakehityksen myötä. Kaikissa tarinoissa asemoituminen uramuuttajaksi vahvistaa siis omaa identiteettiä ja sitä kautta toimijuutta.

Kukin ammattilainen tekee myös identiteettityötä suhteessa omaa elävää määrittäviin ja muutosvaiheessa relevantteihin identiteetteihin, niin menneisiin, nykyisiin kuin tuleviinkin. Uramuutoksessa käydään neuvottelua muun muassa sukupuoleen, ammattiin, ikään, uraan, uskontoihin, harrastuksiin ja perheeseen liittyvien identiteettien välillä (ks. LaPointe, 2011). Toimijuuden mahdollistumisen näkökulmasta on oleellista, millaisia uusia identiteettejä ammattilaiset osaavat kuvitella mahdollisiksi ja sopiviksi. Tässä identiteettityö kokemusten kerronnan kautta on tärkeää. Omissa pohdinnoissaan, keskusteluissa muiden kanssa ja uraohjauksessa ammattilaiset ovat voineet työstää identiteettiään ja löytää uusia vaihtoehtoja. Uramuutoksen toteutus edellyttää muunlaistakin toimintaa identiteetin muokkaamiseksi ja alan vaihtamiseksi.

\section{TOIMIJUUS URAMUUTOKSEN TOTEUTUKSESSA}

\section{Kotiintuloja, uusia kehyksiä ja jatkuvaa etsintää}

Tapasin haastattelemani naiset uudestaan neljä vuotta ensimmäisen kerran jälkeen saadakseni selville, miten heidän uramuutossuunnitelmansa olivat toteutuneet. Kolme heistä oli tehnyt uramuutoksen, kaksi tulkitsi uraansa nyt toisin ja kolme tavoitteli muutosta edelleen. Uramuutoksen tehneet Riitta, Sari ja Maria olivat kaikki vaihtaneet alaa. Aiemmin viestintäalalla ja kotiäitinä toiminut Riitta oli opiskellut teologiksi, saanut pappisvihkimyksen ja työskenteli seurakuntapastorina; Sari oli jättänyt tutkijan tehtävät ja siirtynyt myyntipäälliköksi viiniagentuuriin; ja Maria oli käynyt henkilöstön kehittämistöihin valmentavan koulutusohjelman ja työskenteli edelleen liike-elämässä mutta nyt henkilöstötehtävissä. He kuvaavat riemun tunnettaan mm. kotiin tulemisen metaforin kuten seuraavat lainaukset hyvin kuvaavat:

"Sinä päivänä kun aloitin viiniliikkeessä - no ehkei ihan heti sinä samana päivänä mutta hyvin pian minulle tuli tunne, että tänne minä kuulun. Tämä on ammatillinen identiteettini. Juuri tämä. Olen niiin kotonani, niiin kotonani tällä alalla." (Sari)

"Ja oon viihtynyt aivan hirveen hyvin siis se että sitte ku mä alotin siinä työssä ja mä en ollu kauaakaan tehny niin mul oli semmonen tunne et nyt mä oon tullu kotiin." (Riitta)

Näissä uramuutoksissa on toteutettu toimijuutta: tehty valintoja, hankittu koulutusta, hankittu uusia työpaikkoja, rakennettu uutta identiteettiä. Toimijuutta voi toteuttaa myös toisin, identiteettityön tasolla, kuten uramuutokseen tavoittelusta luopuneiden Eilan ja Tainan tapaukset kuvaavat. He tulkitsivat uraansa nyt uudesta kehyksestä käsin. Laskenta-alan ammattilaisena toiminut Eila oli yrittänyt uutta uraa taloustiedottamisen saralla mutta oli joutunut tekemään laskenta-alan pätkätöitä. Hän ei nähnyt realistiseksi "hypätä johonkin uuteen" hänen "iässään" (56), eikä siten tavoitellut uramuutosta. Kirjoittamista, jonka hän oli löytänyt tärkeäksi uudeksi "identiteetikseen", hän harrasti vapaa-ajallaan aktiivisesti.

Myös Tainan ura oli ollut katkonainen: hän oli ollut työttömänä ja erilaisissa laskentatoimen pätkätöissä. Hän oli alkanut opiskella "ihan omaksi huviksi" lasten ja nuorten hyvinvointia ja suunnitteli myös opettajan pätevyyden hankkimista tulevaisuuden työmahdollisuuksien varmistamiseksi. Hän ei kuitenkaan enää tavoitellut uramuutosta, sillä tultuaan uskoon hän ei enää pitänyt työuraa tärkeimpänä mielekkyyden lähteenään:

"Semmonen sisäinen lepo tai rauha on löytynyt, että ei oo niin se oma tyytyväisyys sidottu näihin ulkoisiin asioihin ja uraan ja menestymiseen ja tämmöseen."

Eeva, Johanna ja Kati tavoittelivat uramuutosta edelleen. Eeva ja Johanna olivat kuitenkin tehneet uusia valintoja ja muutoksia. Eeva oli ehtinyt kuluneiden 
neljän vuoden aikana aloittaa ja saada väitöskirjan loppusuoralle menetettyään työpaikkansa liiketoiminnan kehitystehtävissä it-alan yrityksessä yt-neuvotteluiden yhteydessä. Koska hän ei kuitenkaan halunnut tutkijaksi, oman paikan etsintä työelämässä jatkui.

Johannakin oli vaihtanut työpaikkaa ja edennyt urallaan, mutta työskenteli edelleen laskentatehtävissä ja kaipasi enemmän itsenäisyyttä ja tasapainoa elämäänsä. Kati oli joukosta ainoa, joka oli yhä samassa paikassa, kansainvälisessä hotelliketjussa töissä. Äitiyslomansa jälkeen hän oli kuitenkin alkanut aktiivisemmin etsiä uutta työtä, jossa hänen myyntitaitoja voisi hyödyntää "mielekkäämpien ja kauniiden" asioiden edistämiseen ja harkitsi taidehistorian tai estetiikan opintoja. ${ }^{1}$

\section{Toimijuuden mahdollistajia}

Kuten tutkimani ammattilaisten tapaukset havainnollistavat, toimijuutta voidaan uramuutoksessa toteuttaa monin tavoin, vaikkei uramuutos sellaisenaan toteutuisikaan. Tarkastelen seuraavaksi niitä resursseja, jotka ovat mahdollistaneet tutkimieni naisten toimijuutta muutoksen toteutuksessa ja tulkitsen niitä teoreettisen viitekehykseni valossa.

Uramuutoksen mallitarinat tarjosivat tutkimukseni ammattilaisille kulttuurisesti hyväksyttävät selitykset ja tavoitteet, tietynlaisen identiteettiposition ja siten puitteet toimijuudelle. Uramuutoksen toteuttaneet Sari, Riitta ja Maria tulkitsivat kaikki muutostarvettaan yhteensopimattomuuskertomuksena. Siinä on merkittävää tunne siitä, ettei oma käsitys itsestä ole sopusoinnussa silloisen työn kanssa. Mallitarina pitää yllä aidomman ammatillisen identiteetin ihannetta ja tekee sen tavoittelusta legitiimiä. Kokemus ja tunne yhteensopimattomuudesta kumpuavat kuitenkin oman kokemushistorian muovaamasta subjektiviteetista, joka suuntaa identiteettityötä ja mahdollistaa muutosta. Subjektiviteetti tulee esiin erilaisina tuntemuksina. Esimerkiksi Sari piti tutkijan uraa hyvin palkattuna, arvostettuna asiantuntijatyönä, jossa oli mahdollisuus kehittää itseään. Mitään varsinaista ristiriitaa ei ollut, mutta kuitenkaan hän ei "tuntenut itseään tutkijaksi”. Näin oli myös Riitalla: hän piti viestintätehtävistä mutta ei "tuntenut tekevänsä sitä, mitä hänen oli tarkoitus tehdä". Henkilöstötehtäviin kou- luttautunut Maria taas koki olevansa "liian pehmeä ja ihmisläheinen" ihminen liiketoimintatehtäviin.

Subjektiviteetin merkitys näkyy myös ammattilaisten erilaisissa tavoissa ja kyvyissä tulkita omaa elämää ja kuvitella vaihtoehtoja. Tätä voi havainnollistaa vertaamalla Eevan ja Eilan kertomuksia. Molemmat ovat sujuvia sanoittamaan ja pohtimaan elämäänsä, mutta toimijuuden näkökulmasta Eevalla on monipuolisemmat ja laajemmat resurssit käytössään työelämän jäsentämiseen. Hänellä on kauppatieteellisen koulutuksensa lisäksi myös tutkinto kulttuurintutkimuksesta, hän on työskennellyt niin julkisen sektorin opettajana, yrittäjänä, EU-tehtävissä kuin pörssiyhtiössäkin sekä asunut vuosia ulkomailla. Hän tarkastelee elämäänsä rajoittavia "struktuureja” antropologin linssein ja miettii kiinalaisen lääketieteen innoittamana "miten voisi parhaiten harjoittaa hyveitään” työelämässä. Ryhtyminen jatko-opiskelijaksi kuvaa hänen toimijuuttaan, samoin kuin usko uuden ja mielekkään työn löytymiseen. Eila taas on tehnyt pitkäaikaisen uran julkisella sektorilla ja vastannut lapsiperheen arjesta. Siirryttyään viisikymppisenä ensin pörssiyritykseen ja jouduttuaan sitten työttömäksi hän huomasi, kuinka hänen olisi pitänyt jo aiemmin panostaa uraansa ja ammatilliseen kehitykseen. Nyt hänen ikänsä ja kapean sektorin osaamisensa tuntuivat muodostuvan esteeksi hänen ammatillista identiteettiään vastaavaan asiantuntijatyön löytymiseksi ja hänen oli myös vaikea kuvitella uusia vaihtoehtoja.

Subjektiviteettiin pohjautuva tunne muutostarpeesta ja toimijuuden resurssit eivät muutoksessa kuitenkaan riitä. Uuden ammatillisen suunnan ja identiteetin sanoittaminen on edellyttänyt apua ja uusia resursseja. Riitalle ja Marialle opiskelu tarjosi tällaisen foorumin, jossa identiteettityö pääsi käyntiin. Sarille taas tällaisena identiteetin harjoittelupaikkana toimi työhakemusten kirjoittelu - sen jälkeen, kun hän oli huomannut uraohjauksessa saamiensa harjoitusten jälkeen viiniharrastuksensa olevan ainoa intohimon lähde. Hakemuksia lähetellessä, ja omaa historiaa siitä käsin uudelleen tulkitessa, hän tunsi saavansa vahvistuksen sille, että juuri tälle alalle hän halusi hakeutua. Näin kävi itse myös hotellialalla myyntitehtävissä toimineelle Katille: haettuaan erästä taidemuseon myyntipainotteista tehtävää, hän 
tunsi haastattelukokemuksensa jälkeen saaneensa vahvistusta uudelle suunnalle, vaikkei kyseistä tehtävää saanutkaan. Kaikille yhteinen taho identiteetin työstämisessä oli Sefen uraohjaus. Tässä tutkimuksessa soveltamastani käytäntöteoreettista näkökulmasta käsin voisi ajatella niin, että uraohjaus ei niinkään paljasta ihmiselle erilaisin tehtävin ja testein hänen persoonallisuuttaan ja sen yhteensopivuutta tiettyihin töihin. Sen sijaan se tarjoaa tilan ja resursseja identiteettityölle.

\section{POHDINTA}

Olen analysoinut kahdeksan kauppatieteellisen korkeakoulututkinnon suorittaneen ammattilaisen toimijuutta heidän uramuutospyrkimyksissään. Olen kuvannut, miten toimijuuden tila on avautunut erilaisten katkosten ja jännitteiden kautta ja miten ammattilaiset ovat toteuttaneet toimijuuttaan muutoksen tulkinnan ja identiteettityön kautta muutoksen pohdintavaiheessa. Lisäksi olen kuvannut, miten uramuutospyrkimykset ovat toteutuneet ja mikä muutoksia on mahdollistanut. Uramuutokset ovat ajankohtainen ja relevantti aihe monelle työntekijälle muuttuvassa työelämässä, mutta empiiristä, erityisesti pitkittäisaineistoon pohjautuvaa tutkimusta niiden toteutuksesta on tehty hyvin vähän. Tutkimukseni täyttää tätä aukkoa. Lisäksi tutkimus tarkastelee uramuutoksia toimijuuden näkökulmasta, jonka merkitys työelämän muutoksiin sopeutumisessa on myös aikuiskasvatustieteen piirissä todettu suureksi (Fenwick 2006; Hitlin \& Elder 2007; Eteläpelto ym. 2013).

Tutkimus vastaa erityisesti työurien tutkijoiden peräänkuuluttamaan tarpeeseen tutkia toimijuuden reunaehtoja (Arnold \& Cohen 2008; Tams \& Arthur 2010; Roper ym. 2010), joita yksilöiden toimijuuden itsestään selvyytenä ottavassa tutkimuksessa ja politikassa ei ole huomioitu. Tulokset näyttävät, kuinka työelämän kulttuuriset käytännöt mallitarinoineen sekä subjektiviteetti rajoittavat ja mahdollistavat toimijuutta uramuutoksessa. Lisäksi se osoittaa toimijuuden monimuotoisuuden, sillä uramuutoksen lisäksi toimijuutta voi toteuttaa tulkitsemalla elämäänsä uudelleen, muokkaamalla identiteettiään tai rakentamalla työhön mielekkyyttä muista elämänalueista käsin. Siten tutkimus tarjoaa moniulottei-

\section{UUDISTUMISKERTOMUKSISSA}

\section{P ̈̈̈̈LLIMM ̈̈ISEN̈̈ EI OLE}

\section{ALAN VAIHTO.}

sen kuvan toimijuuden tilasta keskusteluun työurien muutoksista ja yksilön roolista (Arthur \& Rousseau 1996; Briscoe \& Hall 2006, Roper ym. 2010).

Niin yksilön vastuuta korostavan tutkimuksen, median uramuutoksien sankaritarinoiden kuin uusliberalistisessa politiikankin keskiössä on vahvan toimijan ihanne. Tämä uramuutospyrkimysten tutkimus viittaisi siihen, että toimijuuden tilaan sekä sitä rajoittaviin ja mahdollistaviin käytäntöihin tulisi kiinnittää aiempaa enemmän huomiota. Työelämässä kaivattaisiinkin uudenlaisia tapoja vahvistaa työntekijöiden toimijuutta ja vaalia sen monimuotoisuutta. Mielekästä työtä tavoitteleville olisi erityisen tärkeää luoda tietoisesti tilaa uudenlaisille työn tekemisen tavoille. Tutkimuksessani monelle tällainen tila uudelle oli avautunut sattumalta, usein kriisin kautta. Tällöin keho ja mieli ovat irrottautuneet hetkellisesti totunnaisesta tekemisestä, jolloin siihen saa etäisyyttä ja uusia näkökulmia. Tarjoamani käytäntöteoreettisen näkökulman mukaan ollessamme kiinni vanhoissa, totutuissa työn tekemisen tavoissa ja identiteeteissä on vaikea oppia uutta ja muuttua. Arkisesta, automatisoituneesta ja pitkälti tiedostamattomasta toiminnasta on hankala irrottautua pelkällä asioiden pohdiskelulla - siksi uramuutospuhekin lienee yleisempää kuin konkreettiset teot.

Jos oma työ ahdistaa, ei tarvitse jäädä odottamaan irtisanomislappua tai loppuun palamista, jotta asialle voisi jotain tehdä. Harvalle on kuitenkaan mahdollista irrottautua työstä ja sen tarjoamasta taloudellisesta toimeentulosta, jotta voisi pohtia, mitä isona tekisi. Toimijuuden tilaa voi aktiivisesti luoda luopumatta olemassa olevasta työstään. Uraohjaus on tähän tutkimukseen osallistuneille tuonut yhdenlaisen tilan käydä läpi uramuutospyrkimyksiä. Ohjauksen tärkeys on siinä, että se siirtää muutoksen tavoittelun pohdiskelusta toimintaan ja aktiiviseksi työstämiseksi. Koska tutkimukseni keskittyi uramuutoksen jäsentämisen ja identiteettityön käy- 
täntöihin, en tutkinut uraohjauksen vaikutusta tarkemmin. Muutama haastateltava oli kuitenkin saanut ohjauksesta ratkaisevaa apua pohtiessaan uutta ammatillista identiteettiään.

Uramuutoksen pohdinnassa ja uraohjauksessa tulisi keskittyä omien taipumusten pohtimisen lisäksi vahvemmin identiteetin työstämiseen. Se edellyttää huomion kiinnittämistä omaa identiteettiä määrittäviin kulttuurisiin ajattelutapoihin (diskursseihin ja mallitarinoihin) ja käytäntöihin. Millaisia kulttuurisia kertomuksia omassa organisaatiossa, ammatissa tai työelämässä yleensä tarjoillaan siitä, millaisia ammattilaisia/työntekijöitä meidän pitäisi olla? Minkälaisiin oletuksiin ne perustuvat ja millaiset käytännöt niitä ylläpitävät? Tulemalla tietoisemmaksi näistä identiteettiä määrittävistä tekijöistä on helpompi nähdä, miltä osin ne horjuttavat oman työn mielekkyyttä ja saavat ammattilaisen hakemaan joskus tarpeettomastikin muutosta. Etäisyyden ottaminen luo myös tilan, jossa näitä oletuksia voi kyseenalaistaa ja miettiä tapoja tehdä joitakin asioita toisin.

Uusien uravaihtoehtojen pohdinnassa ja sitä tukevassa uraohjauksessa olisi myös kiinnitettävä huomiota uuden ammatillisen identiteetin resurssointiin. Oman subjektiviteetin pohjalta syntyneitä tunteita työn mielekkyyden puutteesta voi alkuun olla vaikea sanoittaa ja kääntää uusiksi uramahdollisuuksiksi. Uuden identiteetin työstämiseen tarvittavia voimavaroja voi lähteä hakemaan olemassa olevista harrastuksista tai jostain uudesta, itseään puhuttelevasta toiminnasta. Oleellista on kuitenkin toiminta - johonkin käytäntöön osallistuminen, jonka kautta voi peilata omaa käsitystä itsestään ja kokeilla uutta ammatillista identiteettiä. Myös koulutus tarjoaa uuden toimintatilan, jossa voi työstää uutta ammatillista identiteettiä ja saada uusia resursseja oman työuransa pohdintaan. Tämä toki edellyttää sitä, että on jo jonkinlainen idea siitä, mitä voisi harkita opiskelevansa. Toinen pienimuotoisempi ja hyvin konkreettinen identiteetin työstämisen paikka on hakemusten ja cv:n kirjoittaminen harkinnassa olevan uuden alan tehtäviin. Sitä kautta voi kokeilla, miten uusi identiteetti resonoisi oman kokemuksen ja subjektiviteetin kanssa.
Nykyisen työelämän puitteissa ammatillisen toimijuuden vahvistaminen tulisi olla niin ammatillisen ja korkeakouluopetuksen kehittäjien, henkilöstöammattilaisten kuin erilaisten työn- ja uraohjaajien työn keskiössä. Toimijuuden vahvistaminen ei tarkoita sitä, että kaikki työmarkkinoiden muutokset pitäisi hyväksyä luonnollisina tai väistämättöminä asiantiloina. Sitä ei myöskään vahvisteta siirtämällä vastuu yksilöille vaan tarjoamalla heille resursseja jäsentää omaa työelämäänsä ja identiteettiään määrittelevää kulttuuria ja käytäntöjä. Samalla on tärkeää avata niitä monitahoisia toimijuuden mahdollisuuksia, joita ammattilaiselle oman subjektiviteettinsa ja luovan toiminnan kautta voi avautua näissä puitteissa.

Tarvitaan myös lisää tutkimusta, joka tarkastelee työntekijöiden subjektiviteettia ja jatkuvaa identiteettityötä yhtenä tekijänä toimijuuden rakentumisessa ja työelämässä oppimisessa (Billett 2006; Eteläpelto ym. 2013). Tässä tutkimuksessa on keskitytty vain keskiluokkaisiin korkeakoulutettuihin naisiin, mutta eri aloilla ja eri työntekijäryhmissä käytännöt ja resurssit identiteettityölle sekä käsitykset työn mielekkyydestäkin vaihtelevat. Olisi myös tärkeää selvittää, millaisia yksilöllisille uramuutoksille vaihtoehtoisia toimijuuden muotoja työelämästä löytyy. Erityisen kiinnostavaa olisi tarkastella työelämää uudistavia kollektiivisia hankkeita, joissa luodaan tilaa mielekkäälle työlle.

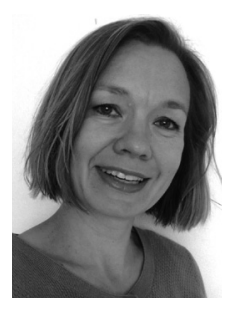

Kirsi LaPointe

KTT, tutkijatohtori Johtamisen laitos Aalto-yliopiston kauppakorkeakoulu 
Alhanen, K. (2013). John Deweyn kokemusfilosofia. Helsinki: Gaudeamus.

Arnold, J. \& Cohen, L. (2008). The psychology of careers in industrial and organizational settings: A critical but appreciative analysis. Teoksessa Hodgkinson, G.P. \& Ford, J.K. (toim.) International Review of Industrial and Organizational Psychology. Vol. 23. 1-44. Chichester: John Wiley.

Arthur, M.B. \& Rousseau, D.M. (1996). The Boundaryless Career: A New Employment Principle for a New Organizational Era. New York, NY: Oxford University Press.

Billett, S. (2006). Work, subjectivity and learning. Teoksessa Billett, S., Fenwick, T. \& Somerville, M. (toim.) Work, Subjectivity and Learning. Understanding learning through working life. UNESCO-UNEVOC Technical and Vocational Education and Training Series 6, 1-20. Dordrecht: Springer.

Blackman, L., Cromby, J. Hook, D., Papadopoulos, D. \& Walkerdine, V. (2008). Creating subjectivities. Subjectivity 22, 1-27.

Briscoe, J. P. \& Hall, D. T. (2006). The interplay of boundaryless and protean careers: Combinations and implications. Journal of Vocational Behavior 69(1), 4-18.

Certeau de, M. (1984). The Practice of Everyday Life. Berkeley: University of California Press.

Davies, B. \& Harré, R. (1990). Positioning: the discursive production of selves. Journal of the Theory of Social Behavior, 20, 43-65.

De Fina, A., Schiffrin, D. \& Bamberg, M. (2006). Introduction. Teoksessa De Fina, A., Schiffrin, D. \& Bamberg, M. (toim.) Discourse and Identity. Studies in Interactional Sociolinguistics 23, 1-23. Cambridge: Cambridge University Press.

Emirbayer, M. \& Mische, A. (1998). What is agency? The American Journal of Sociology 103(4), 962-1023.

Eteläpelto, A., Vähäsantanen, K., Hökkä, P. \& Paloniemi, S. (2013). What is agency? Conceptualizing professional agency at work. Educational Research Review 10, 45-65.

Fenwick, T. (2006). Escaping/Becoming subjects: learning to work the boundaries in boundaryless work. Teoksessa Billett, S., Fenwick, T. \& Somerville, M. (toim.) Work, Subjectivity and Learning. Understanding learning through working life. UNESCO-UNEVOC Technical and Vocational Education and Training Series 6, s. 21-36. Dordrecht: Springer.

Fogde, M. (2011). Governing through career coaching: negotiations of self-marketing. Organization 18(1), 65-82.
Fournier, V. (1998). Stories of development and exploitation: militant voices in an enterprise culture. Organization 5(1), 55-80.

Frost, N. (2009). 'Do you know what I mean?': the use of a pluralistic narrative analysis approach in the interpretation of an interview. Qualitative Research 9(1), 9-29.

Grey, C. (1994). Career as a project of the self and labour process discipline. Sociology: The Journal of the British Sociological Association 28(2), 479-497.

Hall, D.T. (2004). The protean career: a quarter-century journey. Journal of Vocational Behavior 65(1), 1-13.

Hitlin, S. \& Elder Jr., G.H. (2007). Time, self and the curiously abstract concept of agency. Sociological Theory 25(2), 170-191.

Ibarra, H. (1999). Provisional selves: Experimenting with image and identity in professional adaptation. Administrative Science Quarterly 44(4), 764-791.

Ibarra, H., \& Barbulescu, R. (2010). Identity as narrative: Prevalence, effectiveness, and consequences of narrative identity work in macro work role transitions. Academy of Management Review 35(1), 135-154.

Holland, D., Lachicotte Jr., W., Skinner, D \& Cain. C. (1998). Identity and agency in cultural worlds. Cambridge, MA: Harvard University Press.

Hyvärinen, M. \& Löyttyniemi, V. (2005). Kerronnallinen haastattelu. Teoksessa Ruusuvuori, J. \& Tiittula, L. (toim.) Haastattelu. Tutkimus, tilanteet ja vuorovaikutus. Tampere: Vastapaino.

Hyvärinen, M. (2010). Haastattelukertomuksen analyysi. Teoksessa Ruusuvuori, J. \& Nikander, P. \& Hyvärinen, M. (toim.) Haastattelun analyysi. Tampere: Vastapaino.

Julkunen, R. (2008). Uuden työn paradoksit. Keskusteluja 2000-Luvun työprosess(e)ista. Tampere: Vastapaino.

Järvensivu, A. (2010). Tapaus työelämä ja voiko sitä muuttaa. Tampere: Tampereen Yliopistopaino Oy.

Kondo, D. K. (1990). Power, gender, and discourse of identity in a Japanese workplace. Chicago, IL: The University of Chicago Press.

LaPointe, K. (2011). Moral struggles, subtle shifts. Narrative practices of identity work in career transitions. Aalto University Doctoral Dissertations 34.

LaPointe, K. (2013). Heroic career changers? Gendered identity work in career transitions. Gender, Work \& Organization 20(2), 133-146.

Lave, J. \& Wenger, E. (1991). Situated learning and legitimate peripheral participation. Cambridge: Cambridge University Press.

Linde, C. (1993). Life stories: the creation of coherence. New York: Oxford University Press. 
McNay, L. (2000.) Gender and agency. Reconfiguring the subject in feminist and social theory. Cambridge: Polity Press.

McNay, L. (2004). Agency and experience: gender as a lived relation. Sociological Review 52(2), 173-190.

Mishler, E.G. (1986). Research interviewing: context and narrative. Cambridge, MA: Harvard University Press.

Ojala, H. (2010). Opiskelemassa tavallaan. Vanhat naiset ikäihmisten yliopistossa. Tampere: Tampereen yliopistopaino.

Ortner, S. (2005). Subjectivity and cultural critique. Anthropological Theory 5(1), 31-52.

Pringle, J.K. \& Mallon, M. (2003). Challenges for the boundaryless career odyssey. International Journal of Human Resource Management 14(5), 839-53.

Pratt, M.G., Rockmann, K.W. \& Kaufmann, J.B. (2006). Constructing professional identity: the role of work and identity learning cycles in the customization of identity among medical residents. Academy of Management Journal 49(2), 235-262.

Reckwitz, A. (2002). Toward a theory of social practices: A development in culturalist theorizing. European Journal of Social Theory 5(2), 243-263.

Riessman, C.K. (2008). Narrative Methods for the Human Sciences. Thousand Oaks, CA: Sage Publications.

Ronkainen, S. (1999). Ajan ja paikan merkitsemät. Subjektiviteetti, tieto ja toimijuus. Helsinki: Gaudeamus.
Roper, J., Ganesh, S. \& Inkson, K. (2010). Neoliberalism and knowledge interests in boundaryless careers discourse. Work, Employment and Society 24(4). 661-679.

Räsänen, K. \& Trux, M.-L. (2012.) Työkirja. Ammattilaisen paluu. Helsinki: Kansanvalistusseura.

Sandberg, J. \& Tsoukas, H. (2011). Grasping the logic of practice: theorizing through practical rationality. Academy of Management Review 36(2), 338-360.

Sennett, R. (1998). The corrosion of character: The personal consequences of work in the new capitalism. New York, NY: W.W. Norton \& Company.

Sveningsson, S. \& Alvesson, M. (2003). Managing managerial identities: organizational fragmentation, discourse and identity struggle. Human Relations 56(10), 1163-1193.

Tams, S. \& Arthur, M.B. (2010). New directions for boundaryless careers: agency and interdependence in a changing world. Journal of Organizational Behavior 31(5), 629-46.

\section{VIITTEET}

1 Noin vuosi toisen haastattelukierroksen jälkeen olin yhteydessä Katiin ja sain kuulla, että hänkin oli toteuttanut uramuutoksen: hän työskenteli myyntitehtävissä taideliikkeessä. 